\begin{tabular}{|c|c|c|}
\hline 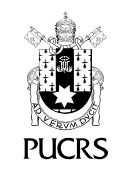 & $\begin{array}{l}\text { ESCOLA DE } \\
\text { HUMANIDADES }\end{array}$ & $\begin{array}{l}\text { Revista Digital do Programa de Pós-Graduação em Letras da PUCRS } \\
\text { Letrônica, Porto Alegre, v. 13, n. 2, p. 1-10, abr.-jun. } 2020 \\
\text { e-ISSN: } 1984-4301\end{array}$ \\
\hline def $\mathrm{http}: / / \mathrm{dx}$ & $\mathrm{rg} / \mathbf{1 0} .15448 / 1984-4301.2020 .2 .35416$ & \\
\hline
\end{tabular}

\title{
Discursos criminalizáveis: proposta de conceituação a partir de cartas de ameaça
}

\author{
Criminalizable discourses: a propose of conceptualization from threatening letters
}

\author{
Welton Pereira e Silva ${ }^{1}$ \\ orcid.org/0000-0002-4693-3151 \\ weltonp.silva@hotmail.com
}

Recebido em: 27 ago. 2019.

Aprovado em: 10 dez. 2019.

Publicado em: 13 ago. 2020.
Resumo: Baseados em estudiosos do discurso (CHARAUDEAU, 2010, 2012; BARROS, 2011), bem como em estudos da Linguística Forense (SHUY, 2005) e do Direito Penal (BITENCOURT, 2010), analisamos duas cartas de ameaça com motivação homofóbica, procurando vislumbrar os imaginários sociodiscursivos que embasam a argumentação intolerante desenvolvida pelos sujeitos enunciadores. Notamos que, à condição homossexual, os sujeitos enunciadores das ameaças associam condutas imorais, orgias, brigas, drogas, bem como a bestialidade, i.e., a aproximação da relação homoafetiva ao animal, ao inumano. Além disso, emergem das cartas conflitos identitários que se assentam sobre a condição homossexual como oposta à identidade de "pessoas de bem" ou "servo de Deus", em um posicionamento explicitamente contrário à comunidade LGBTQI+. Por configurarem discursos de ódio e ameaças, tais discursos podem ser tipificados como crime e, por isso, propomos, neste trabalho, a nomenclatura de discursos criminalizáveis como possiveis objetos de pesquisa na Linguística Forense.

Palavras-chave: Discursos criminalizáveis. Carta de ameaça. Homofobia.

Abstract: Based on discourse researchers (CHARAUDEAU, 2010, 2012; BARROS, 2011), as well as studies from Forensic Linguistics (SHUY, 2005) and Criminal Law(BITENCOURT, 2010), we analyzed two threatening letters with homophobic motivation, seeking to glimpse the socio-discursive imaginary that support the intolerant argumentation developed by the enunciating subjects. We realized that to the homosexual condition, the threatening subjects associate immoral behavior, orgies, fights, drugs, as well as bestiality, the approximation of the homoaffective relationship to the animal, to the inhuman. In addition, identity conflicts emerge from the letters based on the homosexual condition as opposed to the identity of "good people" or "servant of God," in a position explicitly contrary to the queer community. Because they constitute hate speech and threats, such discourses can be typified as a crime and, therefore, we propose, in this work, the nomenclature of criminalizable discourses as possible objects of research in Forensic Linguistics. Keywords: Criminalizable discourses. Threat letters. Homophobic.

"[...] depois que se diz uma coisa, ela está dita, e você tem de arcar com as consequências." Através do espelho e o que Alice encontrou por lá. (Lewis Carroll)

\section{Introdução}

O presente trabalho é um recorte de uma pesquisa maior que se desenvolveu em nivel de doutorado na Faculdade de Letras da UFRJ. A referida pesquisa buscou analisar a argumentação patemizante utilizada em diversas cartas de ameaça, com motivações diferentes, como ameaça por maus tratos a animais, por divida, por traição amorosa, ameaças 
de facções criminosas ao governo etc. Dentre essas, entretanto, chamam a atenção duas cartas cuja motivação para a ameaça gira em torno da orientação sexual dos sujeitos destinatários das cartas, todos identificados como homossexuais. As cartas foram selecionadas a partir da mídia digital, sendo posteriormente transcritas de modo a otimizarmos a análise. Na transcrição, determinadas idiossincrasias ortográficas foram mantidas, visando a mantermos a transcrição o mais fiel possivel às cartas originais.

A análise foi efetuada a partir dos postulados teóricos e metodológicos da Teoria Semiolinguistica do Discurso, proposta por Patrick Charaudeau (CHARAUDEAU, 2010, 2012), bem como se baseia também em outros teóricos do fenômeno enunciativo e discursivo. $O$ foco recaiu sobre os argumentos utilizados pelos sujeitos enunciadores e sobre os imaginários sociodiscursivos que embasam o projeto argumentativo, levando em conta, de igual modo, as escolhas lexicais que demonstrem determinados julgamentos de valor.

Dessa forma, na medida em que a ameaça é tipificada no artigo 147 do Código Penal Brasileiro e levando em conta que a homofobia passou a ser incluida na Lei 9.459, de 13 de maio de 1997, que tipifica os crimes de intolerância racial, social e religiosa, tais enunciados podem ser considerados crimes, após a análise judicial, o que configura os textos aqui analisados como discursos criminalizáveis, ou seja, ações linguisticodiscursivas passiveis de criminalização. Sobre esse conceito, falaremos mais detidamente a seguir.

\section{Os discursos criminalizáveis: breve conceituação}

Em Através do Espelho e o que Alice encontrou por lá, do escritor britânico que assinava sob o pseudônimo de Lewis Carroll, encontramos, em um dos diálogos de Alice com a Rainha Vermelha, a seguinte passagem apresentada na epigrafe do presente artigo: "depois que se diz uma coisa, ela está dita, e você tem de arcar com as consequências" (CARROLL, 2010, p. 188). Nesse livro de fantasia, tido como destinado ao público infantil, temos a reflexão acerca do fato de que nem sempre podemos dizer exatamente aquilo que queremos. Por vezes, ao colocarmos em prática a linguagem, podemos ofender, agredir, violentar nosso interlocutor, estando, portanto, passiveis de sofrer as devidas consequências, legais ou não, por nossos atos.

Quer isto dizer que a faculdade da linguagem, cujo funcionamento é entendido pelas correntes pragmáticas e enunciativas como o colocar em prática uma ação, procurando cumprir um objetivo pré-estabelecido, enseja também ações negativas, não desejadas pelos membros de uma dada comunidade. Quando essas ações agridem a integridade do interlocutor, entretanto, estamos diante de ações linguisticas passiveis de serem tipificadas enquanto crimes, o que poderia levar o locutor a sofrer determinadas sanções judiciais.

No âmbito da Linguistica Forense, há diversos pesquisadores que se debruçam sobre os chamados crimes de linguagem, ou seja, crimes praticados exclusivamente ou principalmente através da língua (SHUY, 2005), tal como a ameaça, a calúnia, a injúria e a difamação. Visto estarmos analisando cartas de ameaça, nosso enfoque pode ser vinculado à Linguistica Forense, campo interdisciplinar que se preocupa com questões relacionadas à linguagem e ao Direito.

Neste trabalho, apresentamos algumas de nossas reflexões que vêm sendo desenvolvidas em pesquisas em nivel de pós-graduação e se debruçam sobre a natureza argumentativa de diferentes crimes de linguagem. Partimos do pressuposto de que, na medida em que a lingua pode ser utilizada como ferramenta em crimes, a prática discursiva engendrada por esse funcionamento da língua em um contexto sócio-histórico é passivel de ser tipificada, isto é, criminalizada. Falamos, portanto, de discursos criminalizáveis, ou discursos que apresentam a possibilidade de serem, após o trânsito em julgado, tipificados como crime.

Antes de definirmos de modo mais proeminente essa terminologia aqui apresentada, é importante ressaltar que, para que uma prática seja considerada criminosa, ela deve apresentar três características. De acordo com o jurista 
Bitencourt (2010), essas características seriam a tipificidade, ou seja, a ação deve ser passivel de classificação em um tipo penal; a antijuridicidade, que diz respeito ao fato de essa prática infringir uma lei; e culpabilidade, já que o transgressor será passivel de punição.

Os discursos criminalizáveis seriam, desse modo, aqueles através dos quais um crime de linguagem é praticado. Seu conteúdo proposicional, ou tema, viabiliza sentidos não costumeiramente aceitos pelos membros de uma dada comunidade sociodiscursiva, em uma determinada época, podendo levar o interlocutor a se sentir aterrorizado, ameaçado, ofendido, injustiçado, violentado, dentre outras possibilidades perlocucionárias. Assim, se geram algum dano ao interlocutor, este tem o direito de se defender ou buscar ser indenizado legalmente de tal dano ofensivo.

Tratando acerca de atos de fala que geram efeitos perlocucionários não preferidos, sendo socialmente mal vistos, Salgueiro (2008) teoriza acerca do que chama de atos de fala hostis, que ocorrem principalmente em situações de conflito:

Precisamente por sua hostilidade, por colocarem em risco a harmonia das relações sociais, tipicamente os atos de fala hostis são socialmente (ou moralmente) mal vistos, e são considerados com reprovação. Além do mais, alguns desses atos verbais são ilegais, já que realizá-los (ou perpretá-los) com sucesso é cometer delitos (ou faltas) com palavras (SALGUEIRO, 2008, p. 5, tradução nossa)².

Salgueiro (2008) se debruça sobre diferentes atos de fala que tendem a ser vistos como descorteses, entretanto, ao fazer menção a atos que servem para praticar um crime, os atos hostis acabam por recobrir algumas ações que apresentam sanção juridica. Enquadramse nessa classificação a calúnia, a injúria e a difamação - conhecidos como crimes contra a honra -, bem como outras ações passiveis de criminalização, como o assédio moral, o assédio sexual, a tentativa de extorsão, a tentativa de estelionato, crimes de ódio, apologias a práticas criminosas e a ameaça, ou seja, os chamados crimes de linguagem, como já explanado.

Tais ações podem ser concretizadas através de diferentes gêneros discursivos, mas apresentam a possibilidade de serem tidas como crime, através do processo chamado por Lenhardt (2019) de criminalização discursiva. Para essa autora, uma prática discursiva pode ser criminalizada após a averiguação das possiveis intenções do enunciador, efetuadas pelo representante legal adequado. É justamente a essas práticas linguísticas passiveis de sofrer o processo descrito por Lenhardt (2019) que chamamos de discursos criminalizáveis. Enquanto a autora se foca sobre o processo judicial, entretanto, nosso foco recai sobre o uso linguístico-discursivo em si, visto como um possivel material de análise no âmbito da Linguística Forense.

Além disso, a exemplo do trabalho de Barros (2011) acerca dos discursos intolerantes, não vemos os discursos criminalizáveis como um único domínio discursivo ou gênero textual/ discursivo. Pelo contrário, tais discursos podem ser encontrados em diversas instâncias sociais, em diversas áreas de atuação humana, tal como preconizou Bakhtin (2003), lembrado por Marcuschi (2017), quando este nos apresenta a noção de Domínio Discursivo.

Desse modo, conforme nos explica Barros:

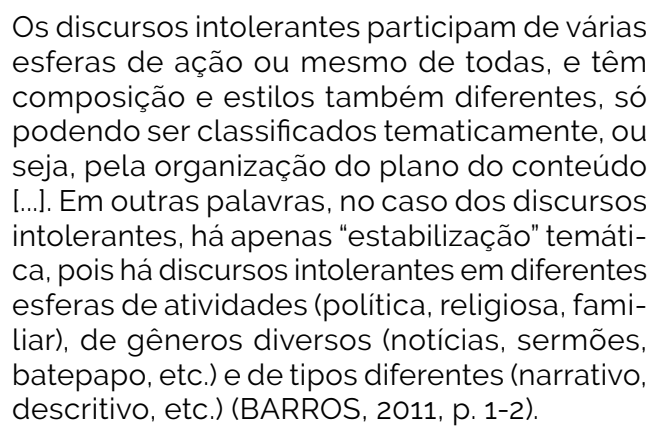

A depender da natureza temática de determinados discursos, de igual modo, poderemos falar em discursos de ódio, assunto amplamente

2 Do original: Precisamente por su hostilidad, por poner en riesgo la armonía de las relaciones sociales, tipicamente los actos de habla hostiles están socialmente (o moralmente) mal vistos, y son considerados con reprobación. Es más, algunos de esos actos verbales son ilegales, ya que realizarlos (o perpetrarlos) con éxito es cometer delitos (o faltas) com palabras. 
discutido na contemporaneidade, principalmente no que concerne a textos veiculados através de redes sociais. De acordo com Meibauer, o discurso de ódio se configura na "[...] manifestação verbal de ódio contra pessoas ou grupos, que ocorre, particularmente, por meio de expressões destinadas à desqualificação e à difamação de grupos populacionais" (MEIBAUER, 2013, p. 1 apud HILGERT; BASTOS NETO, 2017, p. 734).

Isto é, ao procurar deslegitimar, ofender, discriminar, violentar o outro, desapropriando-o de sua condição humana, estamos diante de discursos de ódio. Tais enunciados costumam vir relacionados a determinadas formas de preconceito, como o racismo, a homofobia e a xenofobia. Desta feita, a noção de discursos criminalizáveis que ora apresentamos dialoga sobremaneira com as noções de discursos intolerantes, apresentada por Barros (2011), e de discurso de ódio, trazida por Meibauer (2013 apud HILGERT; NETO, 2017), visto que, por vezes, discursos intolerantes e de ódio são passíveis de criminalização.

\section{Pressupostos teóricos: a Teoria Semiolinguística do Discurso}

As análises que ora apresentamos com o objetivo de ilustrar nossas reflexões acerca do que chamamos de discursos criminalizáveis foram efetivadas a partir dos postulados teóricos e metodológicos da Teoria Semiolinguística do Discurso, proposta por Patrick Charaudeau. Para esse linguista francês, a prática linguageira ocorre sempre a partir de um determinado contrato de comunicação, cujas regras deixam claro o que pode ou não ser realizado na interação. Há, entretanto, um espaço de manobra, no interior do qual o sujeito pode lançar mão de diferentes estratégias, visando a atingir seus objetivos comunicativos.

Dentre essas estratégias, interessa-nos principalmente aquela relacionada à captação, ou seja, ao interesse que o sujeito comunicante tem de influenciar seu interlocutor. Através da estratégia de captação, ocorre a tentativa de fazer com que o interlocutor seja convencido ou persuadido a pensar, agir ou sentir de determinada maneira. No âmbito dos estudos discursivos atuais, a estratégia da captação está intimamente relacionada à problemática do pathos, apresentada desde a retórica aristotélica. O pathos diz respeito às paixões passiveis de ser despertadas no auditório e que, supostamente, contribuiriam para que este concordasse com as teses levantadas pelo sujeito argumentante, ou orador.

Em nossas análises, procuraremos apontar justamente os argumentos que procuram ofender, humilhar, aterrorizar os interlocutores, o que está de acordo com o despertar de emoções. Entretanto, como bem salienta Charaudeau (2010), o despertar de uma determinada emoção está condicionada aos imaginários sociodiscursivos e aos valores compartilhados pelos sujeitos. Assim, um mesmo enunciado pode levar um sujeito a experienciar um sentimento de raiva ou ódio, por exemplo, enquanto leva outro sujeito, que compartilha de outros valores e pontos de vista, a se sentir aliviado ou a experienciar outra emoção.

Outro aspecto salientado por Charaudeau é que:

\begin{abstract}
A análise do discurso não pode se interessar pela emoção como realidade manifesta, vivenciada por um sujeito. Ela não possui os meios metodológicos. Em contrapartida, ela pode tentar estudar o processo discursivo pelo qual a emoção pode ser estabelecida, ou seja, tratá-la como um efeito visado (ou suposto), sem nunca ter a garantia sobre o efeito produzido (CHARAUDEAU, 2010, p. 34, grifo do autor).
\end{abstract}

A emoção é tratada, portanto, como um efeito perlocutório possivel de ser obtido. Ao lançar mão de discursos de ódio, com teor intolerante e preconceituoso, é certo que o sujeito enunciador procurará levar o interlocutor a experienciar emoções de cunho negativo, como o medo, a raiva e a indignação.

Na Teoria Semiolinguística do Discurso, é compreendido também que a prática linguageira se localiza no interior de uma determinada situação de comunicação, sendo essa formada pelo espaço externo, do fazer, e pelo espaço interno, do dizer. Já que estamos no interior das correntes enunciativas, a distinção entre o mundo material e o mundo discursivo acaba por levar à caracterização de quatro sujeitos diferentes, e não apenas dois, tal como é representado na Figura 1. 
Figura 1 - A situação de comunicação

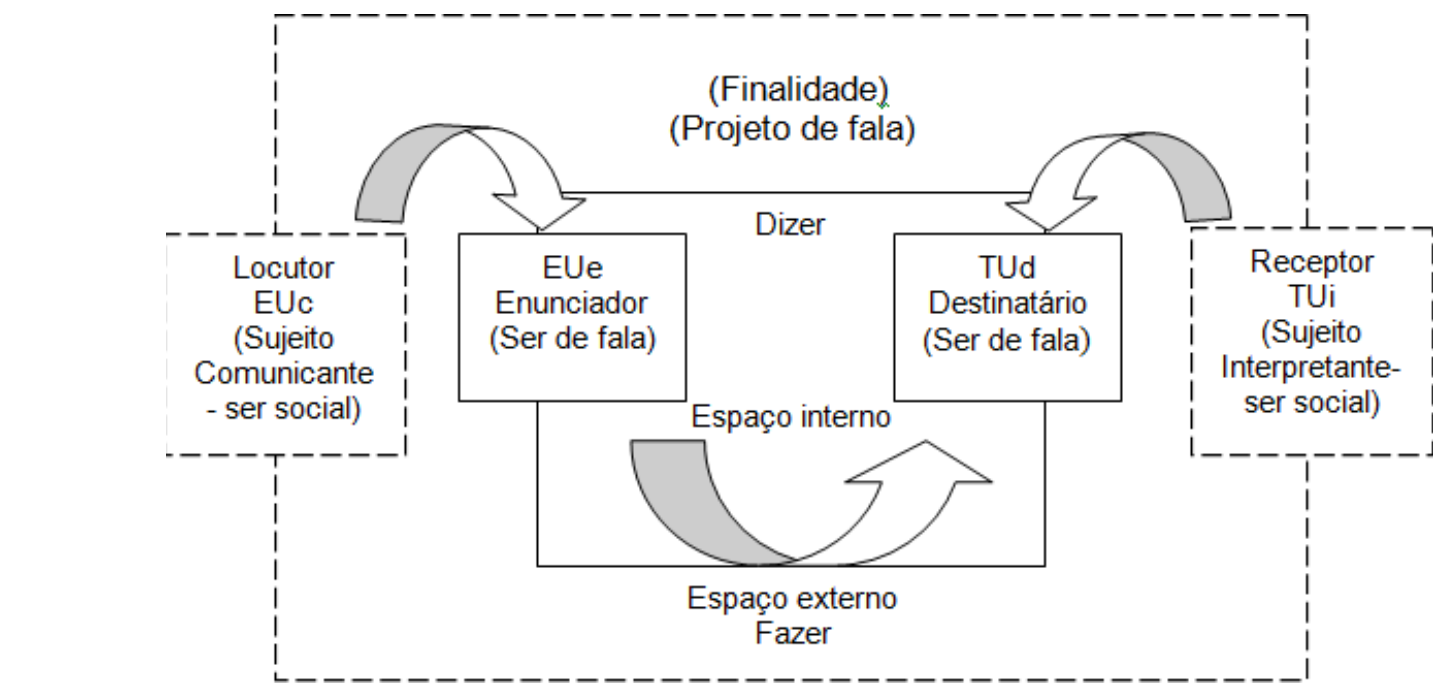

Fonte: adaptada de CHARAUDEAU (2012, p. 52).

A Teoria Semiolinguística do Discurso preconiza que todo ato de linguagem é concebido por um ser empírico, "de carne e osso", o sujeito comunicante. Este, ao enunciar, se projeta enquanto sujeito enunciador, aquele responsável pelo discurso. Nesse processo, o sujeito comunicante tem em mente a imagem do sujeito destinatário, ou o que ele julga ser a identidade desse interlocutor. Por fim, o sujeito interpretante é o sujeito social, também "de carne e osso", sendo o interlocutor efetivo, nem sempre correspondendo ao sujeito destinatário idealizado. Assim, não compete à Análise do Discurso abarcar os sujeitos empíricos comunicante e interpretante. Interessa-nos o fazer discursivo e, portanto, o sujeito enunciador e o sujeito destinatário.

Vale ressaltar, também, que a Teoria Semiolinguística preconiza o que ela chama de semiotização do mundo. Através desse processo, o sujeito enunciador se vale do mundo a significar, transformando-o em um mundo significado. Quer isto dizer que, ao fazer referência ao mundo real, externo, o sujeito imprime sua própria subjetividade.

Ao transformar esse mundo a significar em mundo significado, o sujeito lança mão de quatro formas de organização da matéria linguageira, vale saber, os Modos de Organização do Discurso (CHARAUDEAU, 2012). A partir do modo de organização descritivo, o sujeito nomeia, localiza e situa os seres no/do mundo. Pelos recursos do modo de organização narrativo, o sujeito elenca uma série de acontecimentos no mundo real.

A partir do modo de organização argumentativo, de maior interesse para esta pesquisa, o sujeito parte de uma asserção de partida (uma proposta sobre o mundo) para chegar a uma asserção de chegada (conclusão). Para isso, ele se fundamenta em asserções de passagem (premissas, argumentos, provas). Por fim, Charaudeau (2012) elenca ainda o modo de organização enunciativo do discurso, que influencia na miseenscène dos demais modos. Através do modo enunciativo, o sujeito enunciador se marca em seu próprio discurso (modalidade elocutiva), marca seu destinatário (modalidade alocutiva), ou faz referência a terceiros (modalidade delocutiva). Trata-se de uma posição identitária, bem particular às correntes de base enunciativa.

A seguir, apresentamos as análises concernentes às duas cartas de ameaça que compõem nosso corpus, a partir das quais poderemos melhor compreender os conceitos apresentados nesta seção.

\section{Argumentação em cartas de ameaça por motivação homofóbica}

Visando a perceber como se tecem os argumentos intolerantes em cartas de ameaça com motivação homofóbica, suas características passiveis de tipificação, o que configura tais textos como discursos 
criminalizáveis, lançaremos mão, principalmente, dos postulados teóricos e metodológicos da Teoria Semiolinguística do Discurso, apresentados na seção precedente. Para melhor tecer nossas considerações, trazemos os textos na integra. Segue-se a análise da primeira delas:

\section{Texto I}

Faremos uma limpeza em Betim

A cada um desses que andam pelas ruas declarando seu "amor" bestial traremos o fogo santo da purificação para que quando fizermos nosso papel de apresentá-lo ao senhor Jesus Cristo elas possam passar pela sua aprovação

Esse foi apenas o primeiro caso na cidade a passar pela purificação

Todos os que tivermos acesso passarão também

E esse é o recado que o nosso salvador transmite através de nós seus servos.

Que acabe a abominação da homossexualidade

Que acabe sua sujeira nesse mundo

Amém

A carta acima foi deixada ao lado de um rapaz homossexual agredido por um grupo de individuos que o caluniavam e injuriavam. De acordo com o agredido, as injúrias eram relativas à sua condição homossexual, o que nos permitiu classificar a carta como uma ameaça de agressão por motivação homofóbica.

Pelo teor do texto, podemos perceber que há uma tese implicita, a qual o sujeito enunciador, que se identifica como um grupo plural, procura defender: Betim precisa ser limpa da sujeira da homossexualidade. Embora não esteja marcada verbalmente, a tese pode ser inferida a partir dos argumentos selecionados no decorrer do projeto argumentativo da carta, como no enunciado:

(1) Faremos uma limpeza em Betim

A partir desse enunciado, os sujeitos enunciadores se situam geograficamente, delimitando uma área na qual agirão. Segundo o ponto de vista do sujeito enunciador, conforme afirmamos, "Betim precisa ser limpa da sujeira da homossexualidade". A proximidade garantida com a localização, um recurso do Modo de Organização Descritivo do Discurso, pode favorecer o despertar de diferentes emoções, em um efeito patêmico, nomeadamente na comunidade $L G B T I+$ residente na cidade e região, visto que a carta apresenta, como destinatário, essa comunidade.

Em seguida, o enunciador elenca mais um argumento para comprovar sua tese:

(2) A cada um desses que andam pelas ruas declarando seu "amor" bestial traremos o fogo santo da purificação

O enunciado em apreço é constituído pela modalidade delocutiva (a cada um...) e pela modalidade elocutiva ( $\varnothing$ traremos) do Modo de Organização Enunciativo do discurso, correspondendo aos usos da enunciação da descrição patêmica e da enunciação da expressão patêmica, respectivamente. O destinatário não é nomeado, não consiste em apenas um individuo, mas corresponde a terceiros ausentes - marcados pela modalidade delocutiva -, sendo chamados de "cada um", ou seja, qualquer individuo que se comporte da maneira descrita pelo sujeito enunciador, vale saber, individuos que andam pelas ruas "declarando seu 'amor' bestial": os homossexuais.

É importante perceber que o amor homossexual é questionado, já que o vocábulo que nomeia tal emoção é colocado entre aspas. O enunciador parece não reconhecer o sentimento entre duas pessoas do mesmo gênero como passivel de ser classificado como amor. De acordo com Koch, o uso de aspas é um índice de polifonia, processo a partir do qual se fazem ouvir outras vozes no discurso. Para a autora, "o uso de aspas é frequentemente um modo de manter distância do que se diz, colocando-o 'na boca' de outros" (2015, p. 65).

Assim, ao não concordar com o fato de o amor entre duas pessoas do mesmo gênero ser considerado verdadeiro por grande parcela da população, o sujeito que argumenta insere o vocábulo entre aspas, em uma tentativa de se distanciar da classificação do sentimento entre casais homoafetivos como amor. No processo discursivo, visto essa ser uma marca de subjetividade, o sujeito demonstra que não concorda com essa nomeação, posicionando-se em uma formação discursiva de caráter homofóbico. 
É importante salientar que o ato de relacionar as relações homossexuais à bestialidade e a outros desvios de conduta sexual de natureza patológica é muito recorrente em diversos tipos de discurso, por exemplo, nos de alguns religiosos conservadores que, por vezes, relacionam a homossexualidade à pedofilia. Analisando o discurso do pastor neopentescostal Silas Malafaia, Marques (2016) chama a atenção para o fato de a homossexualidade ser aproximada da bestialidade, o sexo com animais, colocando a relação homossexual muito próxima ao desumano. De acordo com o autor:

A desumanização consiste em deslegitimizar
um grupo retirando traços humanos dessa
comunidade e, além de figurar como recurso
argumentativo, é uma das bases do discurso
de ódio. Negar traços humanos de um grupo
abre margem para ataques discursivos mais
diretos sem que se negative a imagem de
quem ataca, já que não se atacam pessoas,
mas seres divergentes. Além de preservar a
face do endogrupo, a desumanização gera
medo e violência ao criar a realidade discur-
siva do convivio com individuos não humanos,
que fugiriam não somente das caracteristicas
comuns ao que é classificado como humano,
mas também das regras que controlam a vida
humana: ser não-humano representaria risco
à ordem comum (MARQUES, 2016, p. 135-136).

Assim, através do processo de desumanização, é negada ao indivíduo vítima da violência sua condição enquanto ser humano. Na carta em apreço, por exemplo, ao negar a humanidade aos homossexuais, chamando seu amor de bestial, o sujeito enunciador procura preservar sua face, já que ataca alguém que escapa do plano divino e da ordem natural, sendo rechaçado pela sociedade.

É por essa razão que, embora pareça paradoxal, nessa carta, os sujeitos enunciadores não se identificam como criminosos, apesar de terem agredido alguém e ameaçarem agredir outras pessoas pelo fato de serem homossexuais. No texto, os sujeitos enunciadores se apresentam como servos de Jesus Cristo, que detêm o papel sagrado de apresentar as vitimas perante o Senhor, em um processo intertextual. Ainda no que concerne à intertextualidade com o discurso religioso, deparamo-nos com os seguintes enunciados:

(3) Que acabe a abominação da homossexualidade

(4) Que acabe sua sujeira nesse mundo

Os enunciados acima foram construidos com recurso ao modo subjuntivo, configurandose como uma intertextualidade implícita com o gênero oração, como se fosse um pedido, uma súplica a Deus. No enunciado (3), o termo "abominação" veicula uma interdiscursividade com o discurso religioso, já que esse vocábulo é frequentemente utilizado por fundamentalistas cristãos que se baseiam em uma passagem do livro de Levítico, capítulo 20, versículo 13, que afirma: "Se um homem dormir com outro homem, como se fosse mulher, ambos cometerão uma coisa abominável. Serão punidos de morte e levarão a sua culpa".3

De igual modo, o término da carta com a palavra "amém" traz à tona uma relação intertextual com as orações cristãs, principalmente pelo fato de esse termo de origem hebraica designar, no Cristianismo, algo como "assim seja", reiterando que as ameaças devem ser efetivadas, já que são aprovadas.

No enunciado seguinte (4), observamos a qualificação da homossexualidade como algo detentor de "sujeira", ou seja, trata-se de mais um argumento que procura comprovar a tese de que "Betim precisa ser limpa da sujeira da homossexualidade". Há, portanto, um descrédito do comportamento homossexual, ponto de vista que parece ter sido o catalizador da ameaça.

Apresentaremos, agora, a segunda carta analisada, que também apresenta motivação homofóbica, conforme fica evidente logo no primeiro enunciado:

\section{Texto II}

MHJ - Movimento Homofobia Já: Primeiro aviso: nossa comunidade não admite mais estas atitudes imorais em nosso bairro. O Mollon, que sempre foi um bairro de família respeitado com seus idosos e crianças, hoje está habitado ou empesteado por gays, lésbicas, sapatões, seja lá que merda for. Já conseguimos ficar livres 
de duas casas assim, temos nossos métodos. Vocês estão sendo vigiadas 24 horas pela vizinhança. Conhecemos todos que frequentam esta pocilga. Os vizinhos não aguentam mais som alto com músicas de baixo calão, brigas e gritarias até altas horas. Se isso não bastasse, temos fotos e filmes de lésbicas se beijando em frente da casa. Como já disse, temos crianças e pessoas de familia que não são obrigadas a conviver com isso. Se esta é a vida que escolheram viver, vão ter que sofrer as consequências da repugnação das pessoas de bem. Queremos vocês fora daqui. Vão ser felizes no inferno.

Em sua casa nada vai acontecer, mas quando sairem na rua prestem atenção. A polícia e o Conselho Tutelar vão adorar saber que existe uma criança que vive no meio da orgia e drogas. Como eu disse, temos fotos de tudo isso, não somos amadores. Sempre tem um primeiro aviso, depois ação. Gays e negros são lixo. Coisas vão acontecer.

A carta acima foi deixada na casa de um casal lésbico, no ano de 2013. Construido predominantemente com recurso ao Modo de Organização Argumentativo do Discurso, em uma abordagem macroestrutural, observamos, logo no início do texto, a explicitação da tese, vale saber: "nossa comunidade não admite mais estas atitudes imorais em nosso bairro". A partir do momento em que o sujeito enunciador apresenta essa tese, falando em nome de toda a comunidade, ele passa a elencar uma série de argumentos que busca comprovar a tese, com a qual ele concorda. Durante o percurso argumentativo do texto, o enunciador constroi sua imagem como alguém virtuoso, que luta contra aqueles que agem de modo imoral em sua comunidade: o casal lésbico.

Assim, chama a atenção o suposto movimento que se autodenomina $\mathrm{MHJ}$ - Movimento Homofobia Já. Ao contrário de muitos sujeitos comunicantes que produzem discursos com teor homofóbico, mas negam essa fobia, os sujeitos enunciadores dessa carta se apresentam enquanto homofóbicos. Assim, os sujeitos enunciadores dessa carta desejam deixar claras suas intenções homofóbicas e até mesmo racistas, pois encontramos, ao final da carta, o seguinte enunciado:

\section{(5) Gays e negros são lixo.}

Apesar de a carta apresentar motivação homofóbica, o sujeito enunciador insere uma injúria à comunidade negra, além da comunidade LGBTI+. Provavelmente, tal escolha pode estar relacionada ao fato de esses grupos minoritários estarem frequentemente juntos em pautas politicas que defendem o fim da segregação social e racial, bem como lutam pela afirmação de políticas públicas para as minorias.

Desta feita, o sujeito enunciador apresenta um julgamento de valor axiológico a respeito desses dois grupos minoritários, caracterizando-os como "lixo", ou seja, indivíduos sem importância, que podem ser descartados. Essa escolha lexical é corroborada pelo uso do termo "pocilga" para se referir à moradia do casal:

(6) Conhecemos todos que frequentam esta pocilga

De acordo com o dicionário Aurélio4, "pocilga" é sinônimo de chiqueiro de porcos, lugar imundo. Novamente, dentre os possiveis interpretativos desse enunciado, encontra-se o referente à bestialização da condição homossexual. Notamos, portanto, que tanto nesta carta quanto na anterior, a condição homossexual foi designada como suja, pois no primeiro texto os sujeitos enunciadores afirmam que farão uma "limpeza" na cidade de Betim, enquanto, neste, os enunciadores qualificam não apenas os homossexuais, mas também os negros, como lixo.

Trata-se, portanto, de discursos de ódio, intolerantes, o que pode configurar, além do crime de ameaça, previsto no artigo 147 do Código Penal, o crime de injúria, tipificado no artigo 140 do mesmo código. Além disso, recentemente, no Brasil, a homofobia passou a ser incluida na Lei 9.459, de 13 de maio de 1997, que tipifica os crimes de intolerância racial, social e religiosa. Estamos diante, portanto, de discursos criminalizáveis.

Ao final do texto em apreço, deparamo-nos com a ameaça propriamente dita: 
(7) Em sua casa nada vai acontecer, mas quando sairem na rua prestem atenção.

Temos, aqui, uma relação dicotômica entre o espaço da casa e o espaço da rua. Em um, os sujeitos destinatários da carta estão seguros; no outro, devem prestar atenção, pois, conforme o sujeito enunciador atesta ao final da carta:

(8) Coisas vão acontecer.

Nos dois enunciados de ameaça, estamos diante conteúdos semânticos implícitos, já que, para entendermos a ameaça velada, é necessário levar em conta nosso conhecimento linguístico e extralinguístico de modo a inferir que algo ruim pode acontecer aos sujeitos destinatários da carta quando estiverem fora de sua residência.

Atesta-se, assim, que a ameaça não é realizada contra o patrimônio do casal, já que em sua casa nada irá acontecer, mas contra a integridade física das destinatárias da carta. Dessa forma, dentre os sentidos possiveis de serem inferidos a partir desses enunciados, podemos elencar: (1) Em sua casa nada irá acontecer, logo, vocês estarão seguras; (2) [...] mas quando sairem na rua, prestem atenção, pois vocês não estarão protegidas; (3) portanto, coisas ruins vão acontecer com vocês.

Os indices linguísticos que apresentam sentidos passiveis de serem tidos como ameaças são, respectivamente, a solicitação para que as destinatárias da carta "prestem atenção" quando saírem à rua, e o termo genérico "coisas", que acontecerão ao casal. Podemos notar que o sujeito enunciador é assertivo ao afirmar que "coisas vão acontecer", não modalizando seu enunciado, por exemplo, a partir de um verbo modal como o "poder", que denota um sentido de incerteza. Caso essas ameaças surtam o efeito perlocucionário desejado, o de amedrontar as destinatárias da carta, é provável que elas venham a acreditar na tese defendida pelo sujeito enunciador durante todo o percurso argumentativo do texto, vale lembrar, "nossa comunidade não admite mais estas atitudes imorais em nosso bairro".

É notório, nesse texto, que, ao julgar o outro como "lixo", indivíduos que "empesteiam" o bairro e moram em uma "pocilga", o sujeito enunciador se apresenta como o inverso, um morador que não admite atitudes imorais, preocupa-se com crianças e "pessoas de família", além de ele e seus companheiros não serem "amadores" e conhecerem métodos eficazes para se livrar de "casas assim". Nesse discurso, portanto, vislumbramos os matizes de preconceito explícito contra pessoas LGBTI+, sendo atribuidas a elas as "atitudes imorais", "músicas de baixo calão", "orgia e drogas" e o beijo lésbico em frente da casa. A essas pessoas marginalizadas, restam apenas as "consequências da repugnação das pessoas de bem", já que são indesejadas naquele lugar.

Devemos ressaltar, já nos encaminhando para nossas considerações finais, que certos posicionamentos discursivos não devem ser naturalizados, mas desencorajados e mesmo combatidos em prol de uma sociedade mais igualitária e democrática. Um dos papéis da Análise do Discurso é justamente desvelar os sentidos por trás dos enunciados, de modo a contribuir para que a sociedade se torne cada vez mais crítica e emancipada. Assim, a Análise do Discurso, bem como todas as áreas científicas e educacionais, deve procurar contribuir para a construção da plena cidadania e defesa de direitos.

\section{Considerações finais}

Em um país como o Brasil, cuja população LGBTI+ sofre inúmeras perseguições, agressões e humilhações simplesmente pela sua orientação sexual e/ou identidade de gênero, textos como os das duas cartas contendo discursos intolerantes e de ódio aqui analisadas são comuns e, em alguns grupos, aceitos, consumidos e disseminados. De acordo com a ONG Transgender Europe, entre 2008 e junho de 2016, 868 travestis e transexuais foram mortos de forma violenta no Brasil. Em 2017. segundo o Grupo Gay da Bahia, 445 homossexuais foram assassinados. ${ }^{5}$

Tais números fazem parte dos saberes de conhecimento compartilhados em nossa

\footnotetext{
5 Fonte: Rádio Senado. Disponível em: https://www12.senado.leg.br/radio/1/noticia/brasil-e-o-pais-que-mais-mata-homossexuais-no-mundo. Acesso em: 6 nov. 2018
} 
comunidade sociodiscursiva e, assim, subjazem os argumentos de caráter homofóbico produzidos nas cartas em apreço.

Se, no Brasil, tantos homossexuais são assassinados, ameaças de agressão ou de morte motivadas por homofobia são passiveis de despertar sentimentos relativos ao medo, ao terror, à insegurança e ao desespero na população LGBTI+. Isto é, tais ameaças atingiriam de forma satisfatória seus objetivos comunicativos, cumprindo as intencionalidades do sujeito enunciador de fazer-sentir para fazer-crer. Se o sujeito destinatário puder ser amedrontado, possivelmente, acreditará nas ameaças, vindo a realizar aquilo que o sujeito enunciador solicitar.

Percebemos, portanto, que os argumentos e ameaças engendrados nas cartas analisadas são pautados, principalmente, no preconceito e ódio à comunidade LGBTI+. Fica evidente que a orientação sexual das vítimas das ameaças foi fator crucial para que elas fossem efetivadas.

Diante do exposto no presente artigo, a análise linguístico-discursiva, além de nos auxilar a compreender mais a respeito da natureza de textos que veiculam ameaças, aponta para a necessidade urgente de politicas públicas que inibam e punam mais severamente os crimes motivados por qualquer tipo de preconceito, nomeadamente, os relacionados à orientação sexual ou identidade de gênero.

\section{Referências}

BAKHTIN, Mikhail. Estética da Criação Verbal. 4. ed. São Paulo: Martins Fontes, 2003

BARROS, Diana Luz. A construção discursiva dos discursos intolerantes. In: BARROS, Diana Luz Pessoa de (org.). Preconceito e intolerância. Reflexões linguistico-discursivas. São Paulo: Editora Mackenzie, 2011.

BITENCOURT, Cezar Roberto. Tratado de Direito Penal. Parte Geral 1. 15. ed. São Paulo: Saraiva, 2010.

CHARAUDEAU, Patrick. A patemização na televisão como estratégia de autenticidade. In: MENDES, EmíLia; MACHADO, Ida Lúcia. As emoções no discurso. Campinas: Mercado das Letras, 2010. v. II.

CHARAUDEAU, Patrick. Linguagem e discurso: modos de organização. São Paulo: Contexto, 2012.
CARROLL, Lewis. Aventuras de Alice no País das Maravilhas \& Através do Espelho e o que Alice encontrou por lá. Trad. Maria Luiza X. de A. Borges. Rio de Janeiro: Jorge Zahar Editor Ltda., 2010.

HILGERT, José Gaston; NETO, Adalberto Bastos. A irrupção de ódio na internet: traços discursivos de sua manifestação no Facebook. Desenredo, v. 13, n. 3. 2017. https://doi.org/10.5335/rdes.v13i3.7429

$\mathrm{KOCH}$, Ingendore. A inter-ação pela linguagem. São Paulo: Contexto, 2015

LENHARDT, Jordana. Crimes de linguagem: reflexões sobre criminalização discursiva em redes sociais brasileiras. Language and Law/ Linguagem e Direito. v. 6, n. 1, 2019. https://doi.org/10.21747/21833745/ lanlaw/6_1a4

MARCUSCHI, Luiz Antônio. Produção textual, análise de gêneros e compreensão. São Paulo: Parábola, 2017 [2008].

MARQUES, Matheus Odorisi. Homofobia e referenciação: um estudo de caso. 2016. Tese (doutorado em Letras Vernáculas) - Faculdade de Letras, UFRJ, Rio de Janeiro, 2016.

SALGUEIRO, Antonio Blanco. Cómo hacer cosas malas con palabras: actos ilocucionarios hostiles y los fundamentos de la teoría de los actos de habla. Crítica, Revista Hispanoamericana de Filosofía, v. 40, n. 118, 2008. https://doi.org/10.22201/ iifs.18704.905e.2008.1017

SHUY, Roger W. Creating Language Crimes: how law enforcement uses (and misuses) language. New York: Oxford University Press, 2005. https://doi. org/10.1093/acprof:0so/9780195181661.001.0001

\section{Welton Pereira e Silva}

Doutor em Letras Vernáculas - Língua Portuguesa, pela Universidade Federal do Rio de Janeiro (UFRJ, Rio de Janeiro, RJ, Brasil).

\section{Endereço para correspondência}

Welton Pereira e Silva

Universidade Federal do Rio de Janeiro

Faculdade de Letras

Departamento de Lingua Portuguesa

Av. Horácio de Macedo, 2151

Cidade Universitária, 21941-917

Rio de Janeiro, RJ, Brasil 